\title{
Substrates with organic residues in Fritillaria cirrhosa seedlings for bulbus production
}

\section{Substratos com resíduos orgânicos em mudas de Fritillaria cirrhosa para produção de bulbos}

\author{
Ye $\mathrm{Hu}^{1}$; Xuan Liu'; Meng $\mathrm{Ye}^{3 *}$
}

\begin{abstract}
China is abundant in organic residues from agricultural and forestry efforts. Bulbus Fritillaria cirrhosa D. Don (BFC) is a precious wild herb of Liliaceae that grows in the Tibetan area of China and the bulbs are used as a source of medicine. The shortage of germplasm resources restricts the development of traditional Chinese medicinal materials, so improved cultivation methods are urgently needed. The objective of this study was to study the effects of different substrates on the growth of $F$. cirrhosa seedlings. Sawdust and vermi-compost are common organic residues and were selected as nursery materials to supplement efforts to cultivate Fritillaria cirrhosa D. Don from ripe seeds and bulbs. The experiments were conducted in a plastic greenhouse in Ya'an of Sichuan Province from January to May 2013. Vegetative parameters of leaf length, leaf width, seedling fresh weight, seedling dry weight, and bulb size and fresh weight were measured. Additionally, the emergence ratio and preservation rate were calculated. The following results were obtained: (1) Sowing seeds of $F$. cirrhosa with 70\% vermi-compost and 30\% sawdust gave the best emergence rate, leaf length (60 days after seedling emergence, $60 \mathrm{DAS}$ ), and bulb dry weight (at harvest, $93 \mathrm{DAS})$. (2) The leaf nitrogen content (60 DAS) was positively correlated with the nitrogen content of bulbs (at harvest, 93 DAS). From the data, we concluded that forestry residues such as sawdust and vermi-compost can serve as excellent growing substrates of BFC seedlings.
\end{abstract}

Key words: Seedlings. Sawdust. Vermicompost. Vegetative parameters.

\section{Resumo}

A China é abundante em resíduos orgânicos agrícolas e florestais. Fritillaria cirrhosa D. Don, família Liliaceae, é uma planta herbácea que cresce na área da China tibetana, cujos bulbos são utilizados na medicina tradicional chinesa. A escassez de mudas limita o uso deste medicamento, portanto são necessários métodos de cultivo mais eficientes para a multiplicação da planta. O objetivo foi estudar os efeitos de substratos à base de serragem e vermicomposto no crescimento e produção de bulbos de F. cirrhosa. Os experimentos foram realizados em estufa plástica na província Ya'an - Sichuan, de janeiro a maio de 2013. Foram avaliados parâmetros vegetativos de comprimento e largura de folha,

1 Doctoral Student, College of Forestry, Sichuan Agricultural University, Chengdu 611130, Sichuan Province, P.R. China;Bamboo Diseases and Pests Control and Resources Development Key Laboratory of Sichuan Province, Le'shan 614000, Sichuan Procince, P.R. China. E-mail: fuscahuye@163.com

2 Postdoctoral, School of management, Sichuan Agricultural University, Chengdu 611130 Sichuan Province, PR China. E-mail: tedliu7302000@yahoo.com

3 Prof., College of Forestry, Sichuan Agricultural University, Chengdu 611130, Sichuan Province, P.R. China. E-mail: yemeng5581@163.com

* Author for correspondence 
diâmetro longitudinal e transversal de bulbo, massa fresca e seca das plantas e massa fresca e tamanho de bulbos. Além disso, foi calculada a taxa de conservação dos bulbos. O uso de $70 \%$ de vermicomposto $+30 \%$ de serragem provocou maior comprimento de folha aos 60 dias após a emergência das mudas (DAE) e maior massa seca de bulbos (na colheita aos 93 DAE). O teor de N nas folhas (60 DAE) foi positivamente correlacionado com o teor de $\mathrm{N}$ de bulbos (93 DAE). Os resíduos florestais serragem e vermicomposto podem ser usados satisfatoriamente como substratos para $F$. cirrhosa.

Palavras-chave: Resíduos orgânicos. Serragem. Substratos. Vermicomposto. Parâmetros vegetativos.

\section{Introduction}

Soil organic matter provides a reservoir of nutrients for the growth of plants, including nitrogen $(\mathrm{N})$, phosphorus $(\mathrm{P})$, potassium $(\mathrm{K})$, sulphur $(\mathrm{S})$, and micro-nutrients (KHAN et al., 2006). China is abundant in organic resources such as agricultural and forestry residues (AFR) (LIU et al., 2017). Due to the abundant organic matter content of AFR, it can be used as nursery substrate for seed germination and substrate for organism growth (MALINEN; PESONEN, 2001). Reduced tillage and addition of organic residues are environmentally friendly and cost-effective methods to enhance soil organic matter (VICTORIA et al., 2012). Earthworms are microanimals that play at important role in agricultural and forestry ecosystem, playing key roles in the biodegradation of organic residues (LAVELLE, 1996). Vermicompost is the product of the composting process that utilizes various species of worms, and its main nutrients are humic acid, probiotics, amino acids, trace elements, and hormones that stimulate plant growth, such as indole acetic acid (IAA) and gibberellic acid (GA3) (HU et al., 2002). Currently, vermicompost is mainly used to cultivate flowers, fruits, and vegetables (ALBANELL et al., 1988; ATIYEH et al., 2000; CUI; NIU, 1988; ELVIRA et al., 1966; SYERS et al., 1986; ZHUO et al., 2004).

In China, the annual output of forestry residues is 16 billion kilograms (LIU et al., 2017). China is a developing country, and the re-utilization of forestry residues is important not only to protect plant resources, but also to improve the environment. Sawdust is a common form of forestry residue, derived from remainders of trees and wooden products, such as pine sawdust (ZHANG; HE, 2006). Sawdust has physical properties of low specific gravity, good aeration, and good water retention (BENOIT; CEUSTERMANS, 1995; WILSON; CARLILE, 1991). In practice, sawdust is used alone or can be mixed with other substrates (CHENG, 1987; CHEN, 2002; CHEN et al., 2005; SHUKLA et al., 2002; ZHANG; HE, 2006).

The shortage of germplasm resources is a key factor that restricts the development of traditional Chinese medicinal materials (SRIVASTAVA et al., 1996). In China, more than 250 species of medicinal plants are commercially cultivated on about 380,000 ha, including Carthamus tinctorius L., Atractylodes macrocephala Koidz, and Bulbus Fritillaria cirrhosa (BFC). Many cultivated substrates have been studied, including peat, humus soil, and livestock manure (CHEN et al., 1990; CHEN et al., 2005; CANUTO et al., 2012). BFC (Fritillari) is a precious wild herb that is used to relieve cough and eliminate phlegm. It naturally grows in the Tibetan area of China. The bulb is the medicinal part and also the breeding material (CHINESE PHARMACOPOEIA COMMISSION, 2015). "Sprouting"(seeds or bulbs germination) and "sprout tumble" (which defined as the point at which the above ground parts of seedlings became wilted) were observed within a year (EDITORIAL COMMITTEE OF CHINESE ACADEMY OF SCIENCES, 1980). Some substrates have been used to cultivate BFC, such as humus soil, cattle manure, and humus soils supplemented with the dung of Hepialus armoricanus (HU et al., 2013; XIANG et al., 2011; ZHENG et al., 2009). In a field 
experiment, the quality of seedlings grown in humus soils supplemented with the dung of $H$. larvae was significantly better than seedlings grown on nonsupplemented soils. However, the availability of $H$. larvae dung is low and dependent on the number of $H$. larvae. Therefore, it is a bottleneck for the cultivation of high-quality seedlings. According to Table 1, the nutrient content of vermicompost is between the nutrient content of peat and humus soils supplemented with $H$. larvae dung and higher than that of humus soils (CUI et al., 2011; WANG; GUO, 1983).

In this study, we used the nursery mode of a shed at an altitude of 500 meters and tested readily available sawdust and vermi-compost as substrates for the cultivation of ripe seeds of Fritillaria cirrhosa D.Don. The results of this study provide the research basis to effectively cultivate and protect $\mathrm{BFC}$ resources and also recycle agricultural and forestry residues.

Table 1. Vermi-compost contrasts with organic fertilizer, rotten leaf soil, peat in nutrient (\%).

\begin{tabular}{lccccc}
\hline \multirow{2}{*}{ Substrate } & \multicolumn{5}{c}{ Nutrients (\%) } \\
\cline { 2 - 6 } & $\begin{array}{c}\text { Air } \\
\text { porosity }\end{array}$ & $\begin{array}{c}\text { Organic } \\
\text { matter }\end{array}$ & Total N & Total P & Total K \\
\hline Vermi-compost(made in China) & 14.32 & 24.70 & 1.18 & 1.52 & 0.70 \\
Humus soil & --- & 18.44 & 1.16 & 0.66 & 0.45 \\
Humus soils with the dung of Hepialidae Larvae & --- & 26.98 & 1.06 & 0.177 & 1.68 \\
Organic fertilizer & 10.36 & 17.87 & 0.80 & 0.55 & 0.31 \\
Vermi-compost(made in Japan) & 22.24 & 38.35 & 2.07 & 2.42 & 0.69 \\
Peat & --- & 35.94 & 2.01 & 2.17 & 2.24 \\
\hline
\end{tabular}

Note: Data are from (CUI et al., 2011; WANG; GUO, 1983).

\section{Materials and Methods}

\section{Plant material}

Ripe seeds of cultivated Fritillaria cirrhosa D. Don were collected in Sanlong Village, Mao Country, Aba Prefecture, Sichuan Province (Latitude: $103^{\circ}, 85^{\prime} \mathrm{N}$, longitude: $31^{\circ}, 68^{\prime} \mathrm{E}$, altitude: $1580 \mathrm{~m}$ ). Natural stratification was used to break the dormancy of the viable seeds (seeds were buried underground, with relative humidity maintained at $50 \%-60 \%$, and the range of temperature was from 5 to $10{ }^{\circ} \mathrm{C}$ ). After 210 days of natural stratification, the seeds could germinate (Yu et al., 2008).

\section{Nursery substrates}

Decomposed sawdust and vermi-compost were selected as nursery substrates. Decomposed sawdust was collected from the farm of Sichuan Agricultural University and was piled for two years. Vermi-compost was purchased from the 'Si Hong' earthworm farm, Jianyang city, Sichuan Province. Decomposed sawdust and vermi-compost were sterilized with Nandina domestica Thunb. fruit extract and sieved with 10 mesh.

\section{Local conditions}

A micro plot trial was carried out in a plastic greenhouse at Ya'an of Sichuan Province $\left(103^{\circ}\right.$ $01^{\prime} \mathrm{N}$ latitude and $29^{\circ} 54^{\prime} \mathrm{E}$ longitude with an average annual temperature of $15.9{ }^{\circ} \mathrm{C}$, with a mean minimum of $5.1^{\circ} \mathrm{C}$ below zero and a mean maximum of $35.4{ }^{\circ} \mathrm{C}$, and an average annual rainfall of $966.1 \mathrm{~mm})$. The climate of this area is subtropical humid monsoon. 


\section{Breeding experiment}

The trial used a randomized block design with three replicates. There were three plots for each treatment. Each plot was planted with two plug trays (size of plug tray: 200 holes, caliber of $2.5 \times 2.5$ centimeters $(\mathrm{cm})$, length of $54 \mathrm{~cm}$, width of $28 \mathrm{~cm}$, depth of $4 \mathrm{~cm}$, weight of 105-110 gram (g), and made of polystyrene). Twenty-four plug trays were placed in randomized blocks. Four nursery substrates were tested: T1 (100\% vermi-compost), T2 (70\% vermicompost $+30 \%$ sawdust), T3 (40\% vermi-compost + $60 \%$ sawdust), and $\mathrm{T} 4$ (10\% vermi-compost $+90 \%$ sawdust). Sowing was done on 11 February 2013. Two seeds were put in the middle of each hole. After sowing, each plot was put in the greenhouse and received daily illumination of 12 hours, with light intensity of 2000 lux and at a temperature of $15 \pm 2$ ${ }^{\circ} \mathrm{C}$. The plots were regular watered, weeded, and observations were made monthly and the growth status of the seedlings were recorded until harvest.

\section{Statistical analyses}

\section{Chemical properties of nursery substrates}

Samples of sawdust and vermicompost were analyzed for $\mathrm{pH}$ and organic matter contents by the method described by Brake (1992), the total N and hydrolysable $\mathrm{N}$ was measured by Kjeldahl digestion (VAN SCHOUWENBERG; WALINGE, 1973), the total $\mathrm{K}$ and available $\mathrm{K}$ was analyzed by flame analyzer (WINKLEMAN et al., 1986), the total P by spectrophotometer (WATANABE; OLSEN, 1965), and the available P by UV - Vis spectrophotometer (BRAY; KURTZ, 1945). All measurements are listed in Table 2.

Table 2. Chemical characterization of substrates used for cultivating Fritillaria cirrhosa D. Don seedlings.

\begin{tabular}{lcccc}
\hline & \multicolumn{3}{c}{ Treatment } \\
\cline { 2 - 4 } & $\mathrm{T} 1$ & $\mathrm{~T} 2$ & $\mathrm{~T} 3$ & $\mathrm{~T} 4$ \\
\hline $\mathrm{pH}$ & 6.77 & 6.61 & 6.51 & 6.36 \\
Organic matter $(\%)$ & 23.33 & 31.33 & 39.33 & 47.33 \\
Total N (g/kg) & 11.75 & 8.32 & 4.89 & 1.45 \\
Total P (g/kg) & 15.78 & 11.05 & 6.33 & 1.61 \\
Total K (g/kg) & 8.86 & 6.24 & 3.63 & 1.01 \\
Hydrolysable N (mg/kg) & 831.21 & 587.34 & 343.46 & 99.59 \\
Available P (mg/kg) & 333.45 & 236.51 & 139.56 & 42.62 \\
Available K (mg/kg) & 712.17 & 499.22 & 285.27 & 71.32 \\
\hline
\end{tabular}

T1: 100\% vermi-compost; T2: 70\% vermi-compost $+30 \%$ sawdust; $\mathrm{T} 3: 40 \%$ vermi-compost $+60 \%$ sawdust;

T4: $10 \%$ vermi-compost $+90 \%$ sawdust.

\section{Vegetative parameters of F. cirrhosa seedlings}

Seedling emergence indicates the point at which a leaf was exposed from the substrate. At 21 days after sowing, the emergence ratio (ER) of seeds was calculated.

$$
\bullet \mathrm{ER}=(\mathrm{m} / \mathrm{M}) \times 100 \%
$$

Where $\mathrm{m}$ represents the number of seedings that have emerged; $M$ represents the number of seeds sowed. 
Sprout tumble was defined as the point at which the above ground parts of seedlings became wilted. After this occurred, the preservation rate was calculated.

$\bullet P R=（ \mathrm{n} / \mathrm{M} ） \times 100 \%$

Where $\mathrm{n}$ represents the number of harvested bulbs and $\mathrm{M}$ represents the number of seeds sowed.

Plants were harvested 4 June 2013. Harvest was performed when the above ground part of plant had withered. The leaf length, leaf width, bulb longitudinal diameter (BLD), bulb transverse diameter (BTD), seedling fresh weight (SFW), seedling dry weight (SDW), and bulb fresh weight (BFW) were measured. The bulb dry weight (BDW) was determined gravimetrically after drying at 60 ${ }^{\circ} \mathrm{C}$. The value of $\mathrm{R}$ (the ratio of the bulb longitudinal diameter to the transverse diameter) and the value of the bulb's water content were calculated. The total $\mathrm{N}$ in leaf samples and bulb samples was measured by Kjeldahl digestion (VAN SCHOUWENBERG; WALINGE, 1973), the total P was analyzed by spectrophotometer (WATANABE; OLSEN, 1965), and the total $\mathrm{K}$ was measured by flame analyzer (WINKLEMAN et al., 1986).

Statistical analyses were performed using SPSS v19 (SPSS Inc., Chicago, USA). One-way ANOVA with Fisher's LSD tests were performed to examine the vegetative parameters of BFC seedlings under the different treatments. Correlativity analysis was performed to test the relationships between the nutrient content of leaves (60 days after seedling emergence, $60 \mathrm{DAS}$ ) with the nutrient content of bulbs (at harvest, 93 DAS). The significance was determined at $\mathrm{p}=0.05$.

\section{Results and Discussion}

Growth of BFC seedlings

The growth of BFC seedlings was tested under different cultivation conditions. The first day of growth was the day a leaf was exposed from the substrate. 'Sprout tumble' was observed after roughly 60 days and lasted for 33 days, and is defined as the point at which the above ground parts of seedlings became wilted at 60 days of growth. All leaves had decayed and all roots had been broken off at $93 \mathrm{~d}$, and this point was defined as the end of 'Sprout tumble.'

\section{Emergence ratio}

The emergence ratio was the highest in $\mathrm{T} 2$, $62.50 \%$, followed by $\mathrm{T} 1, \mathrm{~T} 3$, and $\mathrm{T} 4$ with ratios of $59.17 \%, 54.25 \%$, and $48.61 \%$, respectively.

\section{Vegetative parameters}

The vegetative parameters of $F$. cirrhosa seedlings were recorded measured and are presented in (Table 3 and Table 4).

As listed in Table 3, at 30 DAS, the value of $\mathrm{R}$ ranged from 1.01 to 1.14 . The BLD, BTD, the mean value of SFW, and the mean value of SDW were highest with $\mathrm{T} 2$ and smallest with $\mathrm{T} 4$. The leaf length was longest with T4, and the leaf width was widest with $\mathrm{T} 2$.

At 60 DAS, the value of $\mathrm{R}$ ranged from 1.08 to 1.18. The BTD ranged from 1.51 to 1.79 , and was highest for $\mathrm{T} 1$ and lowest for T3. The BLD, mean value of SFW, and the mean value of SDW were highest with T2 and lowest with T4. The seedlings grown on T2 had the smallest leaf length at 60 DAS.

According to the data presented in Table 4, there were significant differences in BLD, BTD, R, mean value of BFW, mean value of BDW, and the preservation rate at the time of harvest, 93 DAS. The value of $\mathrm{R}$ ranged from 1.17 to 1.20 . The BLD, $\mathrm{BTD}, \mathrm{BFW}, \mathrm{BDW}$, and preservation rate values were highest with $\mathrm{T} 2$ and lowest with $\mathrm{T} 4$. 
Table 3. Seedling growth parameters of $F$. cirrhosa for different substrates at 30 and 60 days after seedling emergence (DAS).

\begin{tabular}{|c|c|c|c|c|c|}
\hline \multirow{2}{*}{\multicolumn{2}{|c|}{$\begin{array}{c}\text { Indexes } \\
\mathrm{T} 1\end{array}$}} & \multicolumn{4}{|c|}{ Treatment } \\
\hline & & $\mathrm{T} 2$ & $\mathrm{~T} 3$ & $\mathrm{~T} 4$ & \\
\hline \multirow{2}{*}{ Leaf length (mm) } & $30 \mathrm{DAS}$ & $36.91 \pm 0.4491 \mathrm{~b}$ & $37.09 \pm 0.4764 b$ & $38.08 \pm 0.3454 \mathrm{a}$ & $38.89 \pm 0.5300 \mathrm{a}$ \\
\hline & 60 DAS & $40.72 \pm 0.7108 \mathrm{~b}$ & $40.87 \pm 0.5836 \mathrm{ab}$ & $42.40 \pm 0.6623 \mathrm{ab}$ & $42.73 \pm 0.6439 \mathrm{a}$ \\
\hline \multirow{2}{*}{ Leaf width (mm) } & 30 DAS & $0.52 \pm 0.0076 \mathrm{a}$ & $0.52 \pm 0.0067 \mathrm{a}$ & $0.46 \pm 0.0055 b$ & $0.43 \pm 0.0047 \mathrm{c}$ \\
\hline & 60 DAS & $0.58 \pm 0.0065 b$ & $0.62 \pm 0.0050 \mathrm{a}$ & $0.50 \pm 0.0057 \mathrm{c}$ & $0.47 \pm 0.0067 \mathrm{~d}$ \\
\hline \multirow{2}{*}{ BLD (mm) } & 30 DAS & $1.65 \pm 0.1922 \mathrm{a}$ & $1.70 \pm 0.2339 \mathrm{a}$ & $1.49 \pm 0.1395 b$ & $1.36 \pm 0.0796 \mathrm{c}$ \\
\hline & 60 DAS & $1.99 \pm 0.2722 \mathrm{a}$ & $2.02 \pm 0.2479 \mathrm{a}$ & $1.76 \pm 0.2416 b$ & $1.66 \pm 0.2317 \mathrm{c}$ \\
\hline \multirow{2}{*}{ BTD (mm) } & $30 \mathrm{DAS}$ & $1.46 \pm 0.1982 \mathrm{ab}$ & $1.50 \pm 0.2100 \mathrm{a}$ & $1.45 \pm 0.1325 b$ & $1.34 \pm 0.0844 \mathrm{c}$ \\
\hline & 60 DAS & $1.79 \pm 0.2576 \mathrm{a}$ & $1.72 \pm 0.2508 \mathrm{a}$ & $1.51 \pm 0.1684 b$ & $1.55 \pm 0.2154 \mathrm{~b}$ \\
\hline \multirow{2}{*}{$\mathrm{R}$} & 30 DAS & $1.14 \pm 0.1190 \mathrm{a}$ & $1.13 \pm 0.0983 \mathrm{a}$ & $1.03 \pm 0.0753 b$ & $1.01 \pm 0.0384 \mathrm{~b}$ \\
\hline & 60 DAS & $1.12 \pm 0.0597 \mathrm{~b}$ & $1.18 \pm 0.0885 \mathrm{a}$ & $1.17 \pm 0.1434 \mathrm{a}$ & $1.08 \pm 0.0879 \mathrm{c}$ \\
\hline \multirow{2}{*}{$\mathrm{SFW}(\mathrm{g})$} & $30 \mathrm{DAS}$ & $0.9967 \pm 0.1251 \mathrm{a}$ & $1.0130 \pm 0.0188 \mathrm{a}$ & $0.8424 \pm 0.0059 \mathrm{~b}$ & $0.5544 \pm 0.0086 \mathrm{c}$ \\
\hline & 60 DAS & $1.1914 \pm 0.0047 \mathrm{a}$ & $1.2152 \pm 0.0254 \mathrm{a}$ & $1.0270 \pm 0.0078 \mathrm{~b}$ & $0.8420 \pm 0.0054 \mathrm{c}$ \\
\hline \multirow{2}{*}{ SDW (g) } & $30 \mathrm{DAS}$ & $0.1130 \pm 0.0070 \mathrm{~b}$ & $0.1284 \pm 0.0081 \mathrm{a}$ & $0.1023 \pm 0.0131 b c$ & $0.0890 \pm 0.0038 \mathrm{c}$ \\
\hline & $60 \mathrm{DAS}$ & $0.1914 \pm 0.0086 \mathrm{~b}$ & $0.2138 \pm 0.0051 \mathrm{a}$ & $0.1611 \pm 0.0021 \mathrm{c}$ & $0.1080 \pm 0.0101 d$ \\
\hline \multirow{2}{*}{ Moisture rate $(\%)$} & $30 \mathrm{DAS}$ & $88.67 \pm 0.5774 \mathrm{a}$ & $87.33 \pm 0.5774 \mathrm{a}$ & $87.85 \pm 1.2266 \mathrm{a}$ & $83.93 \pm 0.9063 b$ \\
\hline & 60 DAS & $83.94 \pm 0.6573 b$ & $82.40 \pm 0.3606 \mathrm{c}$ & $84.31 \pm 0.3239 b$ & $87.17 \pm 1.1315 \mathrm{a}$ \\
\hline
\end{tabular}

Different letters in a row are statistically different $(\mathrm{p} \leq 0.05)$.

DAS: Days after seedling emergence; BLD: Bulb longitudinal diameter; BTD: Bulb transverse diameter; R: The ratio of longitudinal diameter to transverse diameter; SFW: seedling fresh weight; SDW: seedling dry weight. BFW and BDW data are averages of values from $30 \mathrm{~F}$. cirrhosa samples; T1: 100\% vermi-compost; T2: 70\% vermi-compost + 30\% sawdust; T3: 40\% vermi-compost $+60 \%$ sawdust; $\mathrm{T} 4: 10 \%$ vermi-compost $+90 \%$ sawdust.

Table 4. F. cirrhosa bulb size, weight, and preservation rate at harvest (93 DAS - days after seedling emergence) grown in different substrates.

\begin{tabular}{|c|c|c|c|c|}
\hline \multirow{2}{*}{ Indexes } & & & & \\
\hline & $\mathrm{T} 1$ & $\mathrm{~T} 2$ & T3 & $\mathrm{T} 4$ \\
\hline BLD & $3.35 \pm 0.3062 b$ & $3.46 \pm 0.3643 \mathrm{a}$ & $3.22 \pm 0.4140 \mathrm{c}$ & $2.94 \pm 0.4166 \mathrm{~d}$ \\
\hline BTD & $2.87 \pm 0.2393 \mathrm{a}$ & $2.89 \pm 0.2882 \mathrm{a}$ & $2.70 \pm 0.3133 b$ & $2.49 \pm 0.3624 c$ \\
\hline $\mathrm{R}$ & $1.17 \pm 0.1167 \mathrm{a}$ & $1.21 \pm 0.1548 \mathrm{a}$ & $1.20 \pm 0.1529 \mathrm{a}$ & $1.20 \pm 0.1768 \mathrm{a}$ \\
\hline BFW & $0.5721 \pm 0.0070 \mathrm{a}$ & $0.6072 \pm 0.0378 \mathrm{a}$ & $0.5130 \pm 0.0117 \mathrm{~b}$ & $0.4848 \pm 0.0172 b$ \\
\hline BDW & $0.1167 \pm 0.0008 b$ & $0.1353 \pm 0.0092 \mathrm{a}$ & $0.1147 \pm 0.0031 \mathrm{~b}$ & $0.1030 \pm 0.0039 \mathrm{c}$ \\
\hline Moisture rate (\%) & $79.59 \pm 0.2286 \mathrm{a}$ & $77.73 \pm 0.1442 \mathrm{c}$ & $77.64 \pm 0.2307 \mathrm{c}$ & $78.75 \pm 0.0643 b$ \\
\hline Preservation (\%) & $46.92 \pm 8.5196 \mathrm{ab}$ & $51.52 \pm 6.1130 \mathrm{a}$ & $43.25 \pm 4.9181 \mathrm{ab}$ & $39.25 \pm 5.6513 b c$ \\
\hline
\end{tabular}

Means with different letter in a line are statistically different $(\mathrm{p} \leq 0.05)$.

BLD: Bulb longitudinal diameter; BTD: Bulb transverse diameter; R: The ratio of longitudinal diameter to transverse diameter; BFW: Bulb fresh weight; BDW: Bulb dry weight. BFW and BDW data are averages of 30 F. cirrhosa samples; T1: 100\% vermicompost; T2: 70\% vermi-compost $+30 \%$ sawdust; T3: $40 \%$ vermi-compost $+60 \%$ sawdust; $\mathrm{T} 4: 10 \%$ vermi-compost $+90 \%$ sawdust.

From 30 DAS to 93 DAS, the moisture ratio of bulb were measured and are listed in Table 3 and Table 4. At 30 DAS, the range of values for moisture ratios is [83.93\%-88.67\%]. At $60 \mathrm{DAS}$ and $90 \mathrm{DAS}$, the range of values for moisture ratios was [82.40$87.17 \%]$ and [77.64-79.59\%], respectively. 
All treatments showed significant differences in nutrient content (Figure 1). Nitrogen (N), phosphorus $(\mathrm{P})$, and potassium $(\mathrm{K})$ levelst of $F$. cirrhosa leaf at 60 DAS were significantly higher than the levels at 30 DAS. At 60 DAS the values of leaf nutrient $(\mathrm{N}, \mathrm{P}$, and $\mathrm{K})$ content were highest with $\mathrm{T} 2$. In treatment $\mathrm{T} 2$, the mean $\mathrm{N}$ content was increased by $39.95 \%$, from $16.77 \mathrm{~g} \mathrm{~kg}^{-1}(30 \mathrm{DAS})$ to $23.47 \mathrm{~g} \mathrm{~kg}^{-1}$ (60DAS). The mean P content increased by $25.34 \%$, from $3.721 \mathrm{~g} \mathrm{~kg}^{-1}$ (30 DAS) from 4.664 $\mathrm{g} \mathrm{kg}^{-1}$ (60 DAS). The mean $\mathrm{K}$ content increased by $44.09 \%$, from $14.47 \mathrm{~g} \mathrm{~kg}^{-1}$ (30 DAS) to 20.85 $\mathrm{g} \mathrm{kg}^{-1}(60 \mathrm{DAS})$. At harvest (93 DAS), the highest levels of nutrients in bulbs were the plants grown on T2, followed by T1, and were lowest with T4. In treatment $\mathrm{T} 2$, at harvest (93 DAS), the mean $\mathrm{N}$ content was $28.61 \mathrm{~g} \mathrm{~kg}^{-1}$, the mean P content was $6.960 \mathrm{~g} \mathrm{~kg}^{-1}$, and the mean $\mathrm{K}$ content was 25.32 $\mathrm{g} \mathrm{kg}^{-1}$. Correlation analysis showed a positive correlation of the nutrient levels $(\mathrm{N}, \mathrm{P}, \mathrm{K})$ in leaves (60 DAS) and in bulbs (93 DAS, at harvest) (Table 5). In addition, a significant correlation was found between $\mathrm{N}$ content in leaves and bulbs.

Table 5. Correlation analysis of nutrient content between leaf (60 days after seedling emergence - DAS) and bulb (93 DAS).

\begin{tabular}{cccc}
\hline \multirow{2}{*}{ At $60^{\dagger} \mathrm{d}$ leaf nutrient content } & \multicolumn{3}{c}{ At harvest (93 DAS) bulb nutrient content } \\
\cline { 2 - 4 } & $\mathrm{N}$ & $\mathrm{P}$ & $\mathrm{K}$ \\
$\mathrm{N}$ & $0.990^{*}$ & 0.846 & \\
$\mathrm{P}$ & & & 0.909 \\
$\mathrm{~K}$ & & \\
\hline
\end{tabular}

*indicates significant correlation at $\mathrm{p}=0.05$.

DAS: Days after seedling emergence (DAS).

Figure 1. Effect of substrates (T1, T2, T3, and T4) on nutrient content of $F$. cirrhosa leaf (30 days after seedling emergence - DAS and 60 DAS) and bulb (93 DAS, at harvest).
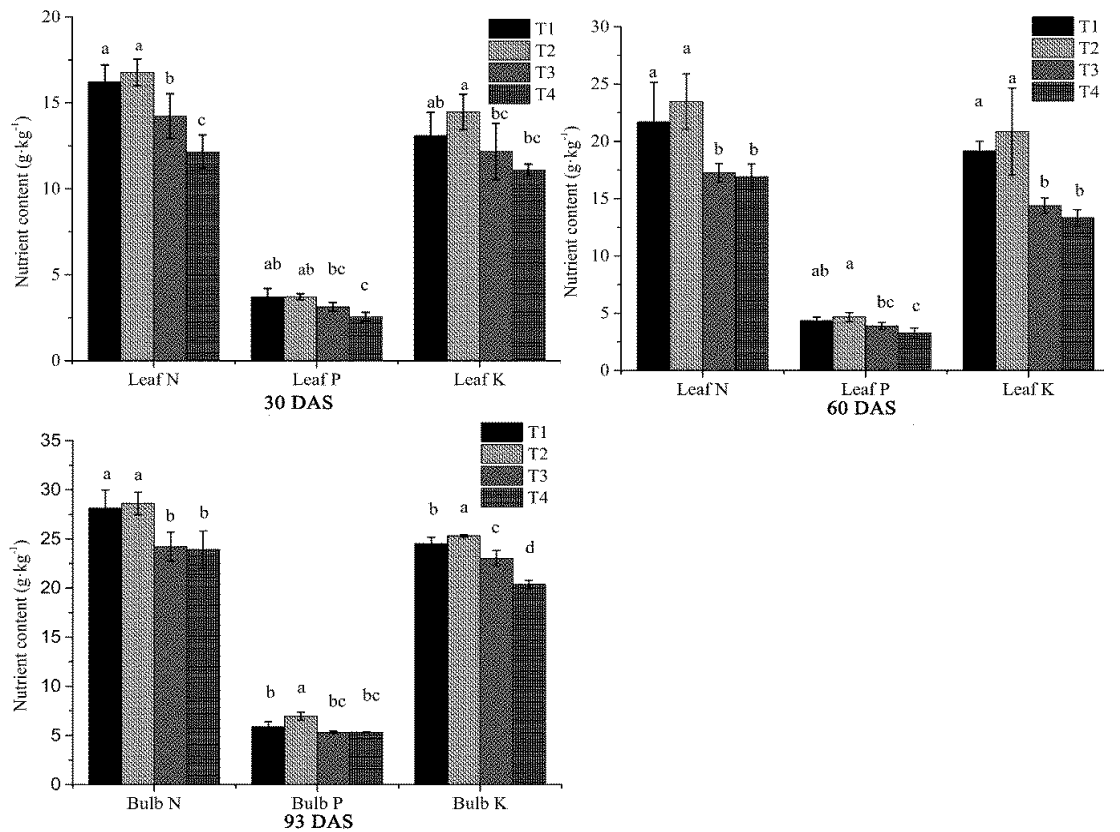

T1: $100 \%$ vermi-compost; T2: 70\% vermi-compost $+30 \%$ sawdust; $\mathrm{T} 3: 40 \%$ vermi-compost $+60 \%$ sawdust; $\mathrm{T} 4: 10 \%$ vermicompost $+90 \%$ sawdust.

Error bars: Data from replicates of each substrate ( $30 \mathrm{~F}$. cirrhosa samples per replicate). 


\section{Discussion}

At 60 DAS, the range of leaf length was [40.72$42.73 \mathrm{~mm}]$ and the range of leaf width was [0.47$0.62 \mathrm{~mm}$ ]. A previous study of the growth of $F$. cirrhosa seedlings by Xiang et al. (2011) found the mean value of leaf length was more than $29 \mathrm{~mm}$ and the mean value of leaf width was more than 0.38 $\mathrm{mm}$. These values are similar to that of the seedlings in our experiments. At harvest, the BLD ranged from 2.94-3.46 $\mathrm{mm}$ and the BTD ranged from 2.49-2.89 $\mathrm{mm}$. A study of relatively high quality F. cirrhosa bulbs by Zheng et al. (2009) reported BLD values of 2.4-3.6 $\mathrm{mm}$ and BTD values of 2.3-3.5 $\mathrm{mm}$. Here, we observed BLD values of 2.4-3.6 mm and BTD values of 2.3-3.5 mm. Based on these comparisons, our observed bulbs and plants were good, suggesting successful use of sawdust and vermicompost for $F$. cirrhosa cultivation.

Forest residues provide cheap and renewable energy. Earthworms play key roles in the biodegradation of those organic residues, producing vermicompost that can be used as a high quality organic fertilizer in horticulture and for the cultivation of fruits and vegetables (ALBANELL et al., 1988; ATIYEH et al., 2000; CUI; NIU, 1988; ELVIRA et al., 1966; SYERS et al., 1986; ZHUO et al., 2004). One aspect of sustainable development in agriculture includes the re-utilization of animal manure and forestry residues to protect plant resources and improve the environment. This study demonstrated improved cultivation using these materials. The highest emergence rate of $62.50 \%$ and highest preservation rate, $51.52 \%$, were observed for plants grown in T2. Therefore, T2 (70\% vermicompost $+30 \%$ sawdust) was the best substrate of the mixtures tested.

At $30 \mathrm{DAS}, 60 \mathrm{DAS}$, and $90 \mathrm{DAS}$, the R values were 1.01-1.14, 1.08-1.18, and1.17-1.21, indicating nearly spherical bulb shape. This result supported the findings of Zheng et al. (2006) and Gao et al. (2012) that first-year plants (sown from seeds) gave rise to bulbs nearly spherical in shape. In other studies, the shapes of two-year-old and three-year-old bulbs exhibited significant deformation (HU et al., 2013; ZHENG et al., 2009), suggesting deformation of bulbs can occur in the second and third year. BFC needs three years of cultivation before harvesting. In China, the bulbs of BFC kept nearly spherical bulb shape, which have high market values (CHINESE PHARMACOPOEIA COMMISSION, 2015; LIU et al., 2008). There is a great risk of artificial cultivation that BFC today face loss of genetic assortment, such as nearly spherical bulb shape (ZHENG et al., 2006). Therefore, bulb get greater attention due to be as the breeding material.

The values of BLD, BTD, BFW, and BDW at 93 DAS were significantly higher than those at 60 DAS (at harvest). This indicated that there was continued growth during this time, despite the wilted appearance of the plants. The $\mathrm{N}$ content of F. cirrhosa leaf was significantly higher at 60 DAS compared to the value at 30 DAS. A significant correlation was found between $\mathrm{N}$ content in the leaf (60 DAS) and in the bulb (at harvest, 93 DAS). We inferred that as the overground part gradually withered, the growth center and photosynthetic products of $F$. cirrhosa gradually transferred from the overground parts of the plant to the underground parts. F. cirrhosa is a Liliaceae plant, and similar nutrient uptake characteristics were observed for onions and lilies (GUO; MA, 2004; ZHANG et al., 1998). The bulbs absorb nutrients from both substrates and the above-ground parts of the plant.

\section{Conclusions}

Sawdust and vermi-compost are suitable as substrate for BFC seedlings. The emergence ratio was the highest, $62.50 \%$, in T2 (70\% vermi-compost $+30 \%$ sawdust). Additionally, the preservation ratio was the highest in T2, 51.52\%. At harvest (93 DAS), BLD, BTD, BFW, BDW, and preservation rate were highest with $\mathrm{T} 2$ and lowest with $\mathrm{T} 4$. Thus, $\mathrm{T} 2$ (70\% vermi-compost $+30 \%$ sawdust) was the best substrate for growth of BFC seedlings. BFC 
needs three years of cultivation before harvesting. The bulbs of BFC kept nearly spherical bulb shape, which have high market values. It is recommended that the vegetative parameters of $\mathrm{BFC}$ seedlings grown on T2 (70\% vermi-compost $+30 \%$ sawdust) remain to be measure in three years. Optimization of composition of $\mathrm{T} 2$ would be an improved practice to harvest high quality bulbs. Importantly, the content of total alkaloid of the three-year-old bulb is measured after harvesting.

\section{References}

ALBANELL, E.; PLAXATS, J.; CABRERO, T. Chemical changes during vermicompost (Elena fetid) of sheep manure mixed with cotton industrial wastes. Biology and Fertility of Soils, New York, v. 6, n. 3, p. 266-269, 1988.

ATIYEH, R. M.; ARANCON, N.; EDWARDS, C. A. Influence of earthworm-processed pig manure on the growth and yield of greenhouse tomatoes. Bio-Resource Technology, Oxon, v. 75, n. 3, p. 175-180, 2000. DOI: 10.1016/S0960-8524(00)00064-X

BENOIT, F.; CEUSTERMANS, N. A decade of research on ecological sound substrates. Acta Horticulturae, Paris, v. 408 , n. 2, p. $17-29$, 1995. DOI: $10.17660 /$ ActaHortic.1995.408.2

BRAKE, J. D. A practical guide for composting poultry litter. Oxon: Department of Poultry Science, Mississippi State University, june 1992. (MAFES Bulletin, 981). Available at: <http://www.msstate.edu/dept/ poultry/ complit.htm>.

BRAY, R. H.; KURTZ, L. T. Determinations of total, organic and available forms of phosphorus in soils. Soil Science, Madison, v. 59, n. 1, p. 39-45, 1945.

CANUTO, K. M.; SILVEIRA, E. R.; BEZERRA, A. M. E.; LEAL, L. K. A. M.; VIANA, G. S. B. Phytochemistry, pharmacology and agronomy of medicinal plants: Amburana cearensis, an interdisciplinary study. Phytochemicals - A Global Perspective of Their Role in Nutrit ion and Health, v.3, n. 1, p. 354-374, 2012.

CHEN, Q. R. Study on container medium of eucalyptus chlorophyll with bagasse and sawdust. Journal of South China Agriculture University (natural Science Edition), Guangzhou, v. 23, n. 2, p. 11-14, 2002.

CHEN, S. C.; HE, C. X.; ZHOU, Z. R.; ZHANG, Z. B. Nutrient absorption characteristics of tomato cultivated with organic substrate in greenhouse. Journal of Plant
Nutrition and Fertilizer, Beijing, v. 11, n. 3, p. 368-374, 2005.

CHEN, S. L.; XIAO, X. H.; CHEN, S. Y. Study on relationship between Fritillaria unibracteata Hsiao et K.C.Hsia quality and soil ecology. Journal of Chinese Medicinal Materials, Guangzhou, v. 13, n. 9, p. 3-5, 1990.

CHENG, B. T. Sawdust as a greenhouse growing medium. Journal of Plant Nutrition, Philadelphia, v. 10, n. 9, p. 1437-1446, 1987.

CHINESE PHARMACOPOEIA COMMISSION. Phamacopoeia of the People's Republic of China (Chinese Pharmacopeia). Beijing: China Medical Science Press, 2015.

CUI, X. W.; LU, Y. X.; LONG, S. P.; LIU, Z. H.; LI, W. Q.; PENG, F. Y. Effect of different agricultural wast nutrition sources on growth of watermelon seedlings. Journal of Southern Agriculture, Nanning, v. 42, n. 9, p. 1087-1090, 2011.

CUI, Y. Z.; NIU, M. F. Effects of earthworm manure on soil fertility and yield and quality of Strawberry. Chinese Journal of Soil Science, Shenyang, v. 29, n. 4, p. 156$157,1988$.

EDITORIAL COMMITTEE OF CHINESE ACADEMY OF SCIENCES (Flora of China). Flora of China. Beijing: Science Press, 1980. 104 p.

ELVIRA, C.; GOICOECHEA, M.; SAMPRDRO, L. Bio-conversion of solid paper-pulp mill sludge by earthworms. Bioresource Technology, Oxon, v. 57, n. 2, p. 173-177, 1966. DOI: 10.1016/0960-8524(96)00065-X

GAO, Y.; QIN, Y. L.; FAN, M. S. Potato tuber forming and growth influenced by nitrogen. The Crop Journal, Beijing, v. 1, n. 6, p. 14-18, 2012.

GUO, Y. H.; MA, W. Q. Nutrient uptake and distibution in oriental hybirds of lily. Chinese Journal of Soil Science, Shenyang, v. 35, n. 6, p. 754-757, 2004.

HU, P.; LIU, D. H.; HU, F.; SHEN, Q. R. Plant hormones in earthworm casts and their promotion on adventitious root formation of mung bean cuuting. Acta Ecological Sinica, Beijing, v. 22, n. 8, p. 1211-1241, 2002.

HU, Y.; YE, M.; DAI, Y.; HAN, K. H. Study on the effects of different media on the seeding of $F$. cirrhosa at plateau. Journal of Agricultural Science, Cambridge, v. 5, n. 12, p. 14-18, 2013.

KHAN, M. M.; KHAN, M. A.; MAZHAR, A.; MUHAMMAD, J.; JASKANI, M. A. A.; HAIDER, A. Evaluation of potting media for the production of rough lemon nursery stock. Pakistani Journal of Botany, Karachi, v. 38, n. 3, p. 623-629, 2006. 
LAVELLE, P. Diversity of soil fauna and ecosystem function. Biology International, Paris, v. 1, n. 33, p. 3-16, 1996.

LIU, H.; CHEN, S. L.; YAO, H.; LI, X. W.; ZHANG, Y. Research progress on resources in bulbus Fritillariae Cirrhosae. China Journal of Chinese Materia Medica, Beijing, v. 33, n. 14, p. 1645-1648, 2008.

LIU, X.; HU, Y.; XIAO, Y. Risk management for rural energy industry of Sichuan province in China. Renewable and Sustainable Energy Reviews, Washington, v. 69, n. 3, p. 1029-1044, 2017. DOI: 10.1016/j.rser.2016.09.084

MALINEN, J.; PESONEN, M. Potential harvest for wood fuels (energy wood) from logging residues and first thinnings in Southen Finland. Biomass and Bioenergy, Oxford, v. 20, n. 1, p. 189-196, 2001. DOI: 10.1016/ S0961-9534(00)00075-1

SHUKLA, A.; ZHANG, Y.H.; DUBEY, P.; MARGRAVE, J. L.; SHUKLA, S. S. The role of sawdust in the removal of unwanted materials from water. Journal of Hazardous Materials, Amsterdam, v. 95, n. 1, p. 137-152, 2002. DOI: $10.1016 / \mathrm{S} 0304-3894(02) 00089-4$

SRIVASTAVA, J.; LAMBERT, J.; VIETMEYER, N. Medicinal plants: an expanding role in development. Washington: World Bank Publications, 1996, 21 p.

SYERS, J. K.; SPRINGETT, J. A.; JIANMIN, J. Earthworms and soil fertility. Advances in Soil Science, Bushland, v. 14, n. 11, p. 45-49, 1986. DOI: 10.1007/97894-009-6101-2 8

VAN SCHOUWENBERG, J. C. H; WALINGE, I. methods of analysis for plant material. Wageningen: Agriculture University,1973. 112 p.

VICTORIA, R.; BANWART, S.; BLACK, H.; INGRAM, J. The benefits of soil carbon: managing soils for multiple economics, social and environmentak benefits. New York: UNEP Year Book, United Nations Environment Programme, 2012. p. 13-39.

WANG, T. K.; GUO, C. Q. Study on the composition and vermicompost. Chinese Journal of Soil Science, Shenyang, v. 5, n. 1, p. 37-40, 1983.

WATANABE, F. S.; OLSEN, S. R. Test of an ascorbic acid method for determining phosphorus in water and
$\mathrm{NaHCO}_{3}$ extracts from soils. Soil Science Society of America Proceedings, v. 29, n. 6, p. 667-678, 1965. DOI: 10.2136/sssaj 1965.03615995002900060025x

WILSON, D. P.; CARLILE, W. R. Storage properties of peat based growing media containing worm worked duck waste. Acta Horticulture, Paris, v.1, n. 238, p. 1323, 1991.

WINKLEMAN, G. E.; AMINE, R.; RICE, W. A.; TAHIR, M. B. Potassium in plant. In: Methods manual soils laboratory. Islamabad: Barani Agric. Res. and Dev. Project. National Agricultural Research Center, 1986. p. $39-40$.

XIANG, L.; HAN, J. P.; CHEN, S. L. Study on the quality of purposive cultivation of Fritillaria cirrhosa seeding. Global Traditional Chinese Medicine, Beijing, v. 4, n. 2, p. 91-94, 2011.

YU, J.; WEI, J. H.; CHEN, S. L.; DAI, Y.; YANG, C. M. Dormancy and gemination characteristics of Fritillaria cirrhosa seeds. Chinese Traditional and Herbal Drugs, Tianjin, v. 39, n. 7, p. 1081-1084, 2008.

ZHANG, X.; ZHU, H. X.; SUN, C. H. Study on nutrients uptake characteristics of Allium sativum and balanced fertilization. Soil and Fertilizer Sciences in China, Beijing, v. 1, n. 2, p. 10-13, 1998.

ZHANG, Y.; HE, Y. Co-composting solid swine manure with pine sawdust as organic substrate. Bioresource Technology, Oxford, v. 97, n. 16, p. 2024-2031, 2006. DOI: 10.1016/j.biortech.2005.10.004

ZHENG, H. J.; XIA, Y. P.; HUANG, C. H.; CHAI, M. L. Studies on bullet development and carbohydrates metabolism in bulbs of Lilium Oriental hybrids grown in mountainous region. Journal of Zhejiang University, Hangzhou, v. 32, n. 5, p. 535-540, 2006.

ZHENG, J.; YE, M.; SUN, Z. C.; DAI, Y.; XIANG, L. Study on the classification of artificial cultivation of Fritillaria Bulb harvest. Chinese Traditional Herbal Drugs, Beijing, v. 40, n. S1, p. 273-276, 2009.

ZHUO, S. M.; LI, Z. G.; PAN, H. D. Influence of vermicompost stored at different stages on raising of cucumber seedlings. Chinese Journal of Tropical Agriculture, Beijing, v. 24, n. 4, p. 11-13, 2004. 